\title{
Getting a job via career-oriented social networking markets
}

\section{The weakness of too many ties}

\author{
Ricardo Buettner ${ }^{1}$ (])
}

Received: 20 June 2016 / Accepted: 26 January 2017 / Published online: 6 March 2017

(c) The Author(s) 2017. This article is published with open access at Springerlink.com

\begin{abstract}
While career-oriented social networking markets (CSNM) such as LinkedIn or XING are increasingly appreciated by a large number of internet users, our understanding of CSNM benefits and factors influencing the intention to use CSNM for a job search is very limited. For theoretical work on CSNM I extend Venkatesh's et al. UTAUT2 model by presenting a new concept considering a user's ties based on Granovetter's social network theory. The evaluation of the extended model, which asks users of CSNM about their job search behavior and their search success, shows a predictive quality increase from 19.0 percent to 80.5 percent. Post hoc analyses reveal a substantial negative relationship between the number of a user's ties and its job search success, which supports the experience of practitioners but contradicts scholarly findings. A level of about 150 contacts is most effective in terms of getting job offers, which confirms Dunbar's number. The results are useful for scholars and practitioners.
\end{abstract}

Keywords Social media - Career-oriented social networking markets $\cdot$ XING $\cdot$ e-HRM $\cdot$ Recruiting · Technology acceptance $\cdot$ Weak ties

JEL Classification C30 $\cdot$ D85 $\cdot$ J44 $\cdot$ M12 $\cdot$ M54

Responsible Editor: Hans-Dieter Zimmermann

Ricardo Buettner

ricardo.buettner@hs-aalen.de

1 Faculty of Business Studies, Aalen University, Aalen, Germany

\section{Introduction}

Electronic markets are becoming more and more enriched by social network (big) data (Alt and Klein 2011; Alt and Zimmermann 2014; Akter and Wamba 2016). Vice versa, the social network big blues (Facebook, LinkedIn, etc.) are increasingly embedding electronic markets business functions in their applications, e.g., career markets (Przemyslaw et al. 2013; Takac et al. 2011). Consequently, more and more companies such as IBM or Microsoft make use of social network applications in order to search for and recruit new employees (Doherty 2010; Madia 2011; Zhou et al. 2012). There is a tremendous increase in professional company profiles on LinkedIn, XING and similar careeroriented online social networking markets (CSNM). Despite some specific challenges when contracting employees electronically (Buettner 2007a, b; Landes and Buettner 2011; Buettner et al. 2013) the market figures, such as 433 mio. registered LinkedIn members, 4 mio. company profiles on LinkedIn, 15 mio. XING members, and 208,000 company profiles on XING, show the significant recruiting potential of CSNM.

In order to clarify the CSNM conception within the information systems area, I define CSNM as a social networking site (SNS, boyd and Ellison (2008)) with electronic market functionality the primary purpose of which is careeroriented (e.g., finding new jobs or employees).

Information systems literature on SNS usage reasoned the intention to use it mainly on the basis of performance and effort expectancies, social influence, facilitating conditions, hedonic motivation, price value, and habit (Venkatesh et al. 2012). Besides this technology acceptance research stream, sociologists mainly argue from a social capital 
theory perspective. For instance, Granovetter stressed the important role of contacts in his famous book "Getting a Job: A Study of Contacts and Careers" (Granovetter 1995). In addition, from a value calculation point of view, it has been coherently argued that the value of a CSNM is primarily based on its membership figures (cf. value-growth curves such as Metcalfe's law, Reed's law, Sarnoff's law, Zipf's law). These scholars argued for an increased (social) network value with every additional contact (Briscoe et al. 2006). In addition, they found positive relations of social media metrics such as membership figures and firm equity values (Luo et al. 2012).

Based on the promising findings by Granovetter (1995) concerning the role of social ties in job markets, in this paper I extend Venkatesh's et al. UTAUT2 model (Venkatesh et al. 2012) by a new concept considering the number of a user's ties in order to explain the CSNM outcome in terms of getting job offers. The evaluation of the model by electronically asking 523 participants aged from 16 to 52 years revealed a very good model fit. Aiming to contribute to the research questions What is the role of the number of contacts in terms of getting job offers via CSNM? $\left(\mathrm{RQ}_{1}\right)$ and What drives the intention to use CSNM for a job search? $\left(\mathrm{RQ}_{2}\right)$, the most important contributions from this work are:

1. By integrating the number of contacts as a new concept in UTAUT2, its predictive quality substantially rises from 19.0 percent to 80.5 percent, $\left(\mathrm{RQ}_{1}\right)$.

2. There is a substantial negative relationship between the number of contacts and job search success, which confirms the gut instinct of professional headhunters (cf. Zanella and Pais 2014, p. 6) and emphasizes the senselessness of simply "collecting contacts" (Donath and boyd 2004), $\left(\mathrm{RQ}_{1}\right)$.

3. Participants who have about 157 contacts reported the highest level of job offer success, which confirms Dunbar's number of $150\left(\mathrm{RQ}_{1}\right)$.

4. Resources and knowledge about job search functions in CSNM mainly drive job search intentions, which confirms results from new institutional economics about job search markets (e.g., McCall 1970; Spence 1973), $\left(\mathrm{RQ}_{2}\right)$.

5. In contrast to prior research from human resources concerning offline job search behavior (e.g., Van Hooft et al. 2012), I found evidence that habit plays an important role in building job search intention in CSNM, $\left(\mathrm{RQ}_{2}\right)$.

The results are useful for scholars and practitioners. For scholars I will show potential for further IS-theorizing of (C)SNM usage. In addition, while past research has focused on general motives for job search intention (e.g., Thatcher et al. 2012), there is not much knowledge concerning the usage of (C)SNM for job search activities. This work shed light on (C)SNM usage for the job search, which is also fruitful for both CSNM operators and users. Operators can improve CSNM by sophisticating the job search functions and its explanations. Users benefit from the insight that simply "collecting contacts" (cf. Donath and boyd 2004) does not make sense in terms of getting job offers. This insight is interesting because it was found that SNS users primarily construct their network on the basis of expectations regarding the value of networking (Krasnova et al. 2010) and a level of about 150 contacts works most effectively (cf. Dunbar 2003). To the best of the author's knowledge no CSNM specific investigation exists that empirically analyzes the relationship between jobseekers' centrality and success in terms of getting job offers.

The paper is organized as follows: Next I extend the UTAUT2 model by considering the number of a user's ties within the new model and derive the associated hypotheses from theory. After that the model evaluation methodology, including the sampling strategy and all measurements are presented, before the results, including the sample characteristics and the structural model, are shown and discussed. Finally, the conclusion is presented, including limitations and future research.

\section{Research background, research model and hypotheses}

\section{Technology acceptance literature on social networking markets}

The big blue social networking companies such as Facebook, LinkedIn, or XING are integrating more and more career-oriented functionalities in their applications (e.g., Smith and Kidder 2010; Caers and Castelyns 2011; Madia 2011; van Dijck 2013; Ollington et al. 2013). In addition, companies are integrating social network features and sites into the internal HR processes, e.g., social software (Raeth and Smolnik 2010), employee portals (Sugianto and Tojib 2006; Urbach et al. 2010, 2011), business-toemployee-portals (Sugianto and Tojib 2006; Tojib et al. 2008), enterprise social software platforms (Kügler et al. 2013; Steinhueser et al. 2015), intra-organizational electronic networks (Teigland et al. 2006), enterprise social networks (Cao et al. 2013). The interest in understanding the benefits and the acceptance factors of these careeroriented social networking sites and markets is consequently high.

Research on technology acceptance in the online social network and consumer context has been dominated by the Theory of Reasoned Action (TRA), Theory of Planned Behavior (TPB), Technology Acceptance Model (TAM+), Unified Theory of Acceptance and Use of Technology (UTAUT+), IS Continuance Model (CM), Multi Attribute 
Utility Theory (MAUT) (Buettner 2015c, p. 1). The most prominent models used for SNS analysis were TAM+, and UTAUT2 (e.g., Oechslein et al. 2014). Venkatesh's et al. UTAUT2 model is the most widely accepted theory within the consumer domain and it "extends the unified theory of acceptance and use of technology (UTAUT) to study acceptance and use of technology in a consumer context" (Venkatesh et al. 2012, p. 157). Since the UTAUT2 model aims to study the behavior of end users (consumers) in contrast to business users, which were primary covered by UTAUT and TAM+, UTAUT2 is the theoretical base used in this work.

\section{On the economic value of social ties}

Scholars from different disciplines coherently argue that in principle - social ties are fruitful on an individual and an organizational level. For instance, from a value calculation point of view it is argued that the value of a CSNM is primarily based on its membership figures (cf. value-growth curves such as Metcalfe's law, Reed's law, Sarnoff's law, Zipf's law). These scholars argue for an increased (social) network value with every additional contact (Briscoe et al. 2006). In addition, positive relations of social network metrics such as membership figures and firm equity values were found (Luo et al. 2012).

On an individual level and most related to career success in terms of getting job offers, Granovetter (1995) already stressed the very important role of contacts already some decades ago. An increased number of contacts (as the most common network centrality measure (Shaw 1954; Freeman 1977, 1978; Borgatti and Everett 2006)) is better for a member in terms of career-oriented success. Confirming this speculation, prior research on offline career-oriented networks found positive relationships between network centrality and career success (Seibert et al. 2001; Mehra et al. 2006) as well as individual (Baldwin et al. 1997) and group performance (Sparrowe et al. 2001). In addition, scholars argued that "SNS make a larger contact pool available to their members and allow them to easily manage and maintain virtually unlimited numbers of contacts by granting access to the long tail of social networking - an additional pool of contacts that is inaccessible via traditional networking" (Enders et al. 2008, p. 209). Furthermore, prior research found evidence that the number of recruiters' contacts implies greater success in recruiting (Gandal et al. 2009).

However, professional "recruiters seem to distrust the number of contacts [of an applicant] as a sort of 'noisy' information" (Zanella and Pais 2014, p. 6) and other scholars from human resources such as Wanberg et al. (2000) found no relationships between offline networking centrality and offline reemployment success.
Based on the theoretically argued importance of the number of contacts on an individual and an organizational level in relation to the opposite findings of practitioners, it is very interesting to study its role in more detail. Such a study on the role of the number of contacts in career-oriented social network markets is of very practical relevance since the incorporation of CSNM is a very promising development in electronic human resource management (Buettner and Landes 2012; Buettner 2014, 2015a, b, 2016c, e). Envisioned thirty years ago by Macdonald (1986), job search via CSNM has actually emerged as an important application channel (Keim 2007; Zhang and Ackerman 2005; Caers and Castelyns 2011). Nowadays scholars and practitioners coherently argue the increased importance of CSNM for a job search (Doherty 2010; Madia 2011; Zhou et al. 2012; Kuhn and Mansour 2014). For instance, Kuhn and Mansour (2014) found that "unemployed persons who look for work online are re-employed about $25 \%$ faster than comparable workers who do not search online" (p. 12).

The subsequently extended research model is shown in Fig. 1.

Next, an explanation will follow as to how the hypotheses were derived from theory.

\section{Antecedents of the intention to use social networking sites for a job search}

Plummer and Hiltz (2009) and Plummer et al. (2011) proposed a research framework to explain Behavioral Intention concerning a job search via SNS. They found substantial effects of Performance Expectancy and Effort Expectancy on Behavioral Intention. These influences were also theorized by Davis (1989) and Venkatesh et al. (2003) and Venkatesh et al. (2012) within TAM(++) and UTAUT(2). That is why I hypothesize:

$\mathrm{H}_{1}$ : Performance Expectancy will be positively associated with Behavioral Intention.

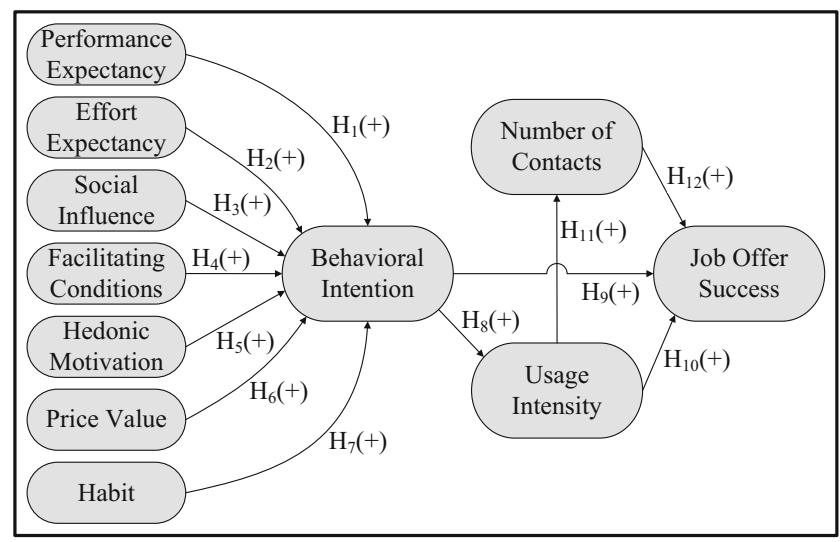

Fig. 1 Research model 
$\mathrm{H}_{2}$ : Effort Expectancy will be positively associated with Behavioral Intention.

Tan et al. (2014) analyzed how SNSs affect job choice intention and found a moderate peer group influence. This kind of Social Influence was also conceptualized by Venkatesh et al. (2012). I hypothesize:

$\mathrm{H}_{3}$ : Social Influence will be positively associated with Behavioral Intention.

New institutional economics theorized that sufficient resources and knowledge about systems, processes and market functions are critical components for the success of both the individual and the whole economy (Alchian 1969; Alchian and Demsetz 1972; Stigler 1961). That applies in particular to a job search (McCall 1970; Spence 1973). Venkatesh et al. (2012) theorized the impact of sufficient resources and knowledge in terms of system usage on Behavioral Intention. Thus I hypothesize:

$\mathrm{H}_{4}$ : Facilitating Conditions will be positively associated with Behavioral Intention.

Brecht and Eckhardt (2012) found that humanities graduates use SNSs predominantly for entertainment purposes. Since general technology acceptance research also largely theorized the importance of Hedonic Motivation in terms of using IS (van der Heijden 2004; Hassenzahl 2001; Venkatesh et al. 2012), I consequently hypothesize:

$\mathrm{H}_{5}$ : Hedonic Motivation will be positively associated with Behavioral Intention.

Venkatesh et al. (2012) theorized that "the cost and pricing structure may have a significant impact on consumers' technology use" (p. 161). Consumers usually bear the monetary cost of such use (Dodds et al. 1991). Following Venkatesh et al. (2012) I define Price Value as "consumers, cognitive tradeoff between the perceived benefits of the applications and the monetary cost for using them" (p. 161) and therefore hypothesize:

$\mathrm{H}_{6}$ : Price Value will be positively associated with Behavioral Intention.

IS scholars (e.g., Kim et al. 2005; Limayem et al. 2007) and psychologists (e.g., Ouellette and Wood 1998) have largely theorized the influence of Habit on Behavioral Intention. LaRose and Eastin (2004) showed that internet habit strength will be directly related to internet usage intention. Habit was also theorized as important for social media usage intention (Hutto and Bell 2014; Nikou and Bouwman 2013). I consequently theorize:

$\mathrm{H}_{7}$ : Habit will be positively associated with Behavioral Intention.

\section{Antecedents of job offer success}

IS acceptance research (e.g., Davis 1989; Venkatesh et al. 2003, 2012), has coherently theorized a positive relation between Behavioral Intention and Usage Intensity. That is why I hypothesize:

$\mathrm{H}_{8}$ : Behavioral Intention will be positively associated with Usage Intensity.

Saks (2006) found that the intensity of a job search is a predictor of job offers. Also the meta-analysis by Kanfer et al. (2001) revealed a moderate positive relationship between job search behavior and the number of job offers. Against this background I hypothesize:

$\mathrm{H}_{9}$ : Behavioral Intention will be positively associated with Job Offer Success.

$\mathrm{H}_{10}$ : Usage Intensity will be positively associated with Job Offer Success.

Research on the impact of Usage Intensity on forming social ties has generated conflicting results (Zhao 2006). Kraut et al. (1998) coined the phrase "Internet paradox" meaning that increased internet usage decreases the size of a user's social network. In contrast, Zhao (2006) revealed that "social users of the Internet have more social ties than nonusers do" (p. 844). Gonçalves et al. (2011) also found a positive relationship between SNS usage and the Number of Contacts. Robinson and Martin (2010) also found contradictory results. While reading, for example, was associated with increased IT media use, the IT media usage level was not consistently correlated with levels of socializing or other social activities (Robinson and Martin 2010). Since Kraut et al. (2002) showed that the negative effects reported in Kraut et al. (1998) dissipated over time and the majority of scholars found positive consequences in SNS usage concerning the building and maintaining of social contacts, I hypothesize that:

$\mathrm{H}_{11}$ : Usage Intensity will be positively associated with the Number of Contacts.

At first glance it also sounds plausible that an increased number of contacts (as the most common network centrality measure (Shaw 1954; Freeman 1977, 1978; Borgatti and Everett 2006)) is better for a member in terms of career-oriented success. Confirming this speculation, prior research on offline career-oriented networks found positive relationships between network centrality and career success (Seibert et al. 2001; Mehra et al. 2006) as well as individual (Baldwin et al. 1997) and group performance (Sparrowe et al. 2001). An increased number of contacts increases the probability of bridging structural holes (Burt 1992) and of also having more weak ties (Granovetter 1973). "In this sense, networks can help us cover more space; they 
can enable us 'to be there without being there" (Rangan 2000, p. 823). Furthermore, since various value-growth curves (Metcalfe's law, Reed's law, Sarnoff's law, Zipf's law) coherently argue for an increased (C)SNM value with every additional contact (Briscoe et al. 2006), the value calculation point of view also leads to the belief in a positive relationship between the number of contacts and the number of job offers. In addition, most of the practitioners affirmed that there were greater job opportunities due to an increased contact pool in CSNM (e.g., Doherty 2010; Madia 2011). "SNS make a larger contact pool available to their members and allow them to easily manage and maintain virtually unlimited numbers of contacts by granting access to the long tail of social networking - an additional pool of contacts that is inaccessible via traditional networking" (Enders et al. 2008, p. 209). However, some "recruiters seem to distrust the number of contacts as a sort of 'noisy' information" (Zanella and Pais 2014, p. 6) in CSNM and also some scholars did not find any relationship between networking centrality and (re-)employment success in offline career-oriented social networking (e.g., Wanberg et al. 2000). Hence, the question arises if the Number of Contacts is important in terms of getting job offers or is it just "the illusion of community" (Parks and Floyd 1996)? Since the majority of scholars theorized a positive relationship between the Number of Contacts and Job Offer Success, I will evaluate this for CSNM and consequently hypothesize:

\section{$\mathrm{H}_{12}$ : Number of Contacts will be positively associated} with the Job Offer Success.

\section{Methodology}

\section{Sampling strategy}

In order to evaluate the research model, working professionals who studied extra-occupationally at FOM university were recruited. The participants were asked electronically to take part in a survey concerning career-oriented social networking sites (CSNS) such as XING - an important network in Europe. The call for participation was sent out with a link to the online questionnaire via the Germany-wide university.

\section{Measurements}

All constructs of the research model (Fig. 1) were operationalized by proven and established measurement instruments (see Table 1). Each item, with the exception of Number of Contacts, was measured using a 7-point Likert scale. Furthermore, sociodemographic data for each participant were captured.

\section{Results}

\section{Sample characteristics}

Data were collected via an online-based questionnaire. 524 completed questionnaires were received. After removing one invalid questionnaire which consistently showed an equal answer pattern (maximum was always clicked), 523 questionnaires $(\sim 99.8 \%)$ were used within the analysis. The remaining participants were aged from 16 to 52 years $(\mathrm{M}=26.9$, S.D.=4.9). $271(\sim 51.8 \%)$ of the test persons were female, 251 male. One participant did not answer the question concerning sex.

354 participants used XING and 97 individuals used an internal (company) social networking site. 222 participants actively used its career-oriented social networking market to find new jobs.

\section{Evaluation of the measurement model}

Following the recommendations by Ringle et al. (2012), item wording, scales, scale means and standard deviations for all measures are reported in Table 1. Following the standard guidelines (Hair et al. 2014; Urbach and Ahlemann 2010; Henseler et al. 2009), reliability and validity measures will be reported in Table 2. Please note that within the measurement model nine constructs with reflective indicators and two formative constructs were used (cf. Petter et al. 2007).

\section{Reflective constructs}

Following the guidelines by Hair et al. (2014) and Urbach and Ahlemann (2010), internal consistency reliability, indicator reliability, convergent validity and discriminant validity for the evaluation of the reflective measurements are reported in the following.

Internal consistency reliability: The internal consistency of all constructs is given, as both values, Cronbach's $\alpha$ and Composite Reliability CR, were greater than .7 for each construct (see Table 2, cf. Revelle (1979) and Nunnally and Bernstein (1994)).

Indicator reliability: The variance of a latent construct extracted from a specific item should be greater than .5 which means that the factor loadings of the indicators should be above .7(07) (Carmines and Zeller 1979; Hair et al. 2011). This condition is fulfilled for all indicators with no exception (see Table 1). In addition, the factor loadings were all significant at a $\mathrm{p}<.001$ level (nonparametric bootstrapping procedure according to Efron and Tibshirani (1993) with 5,000 samples). 


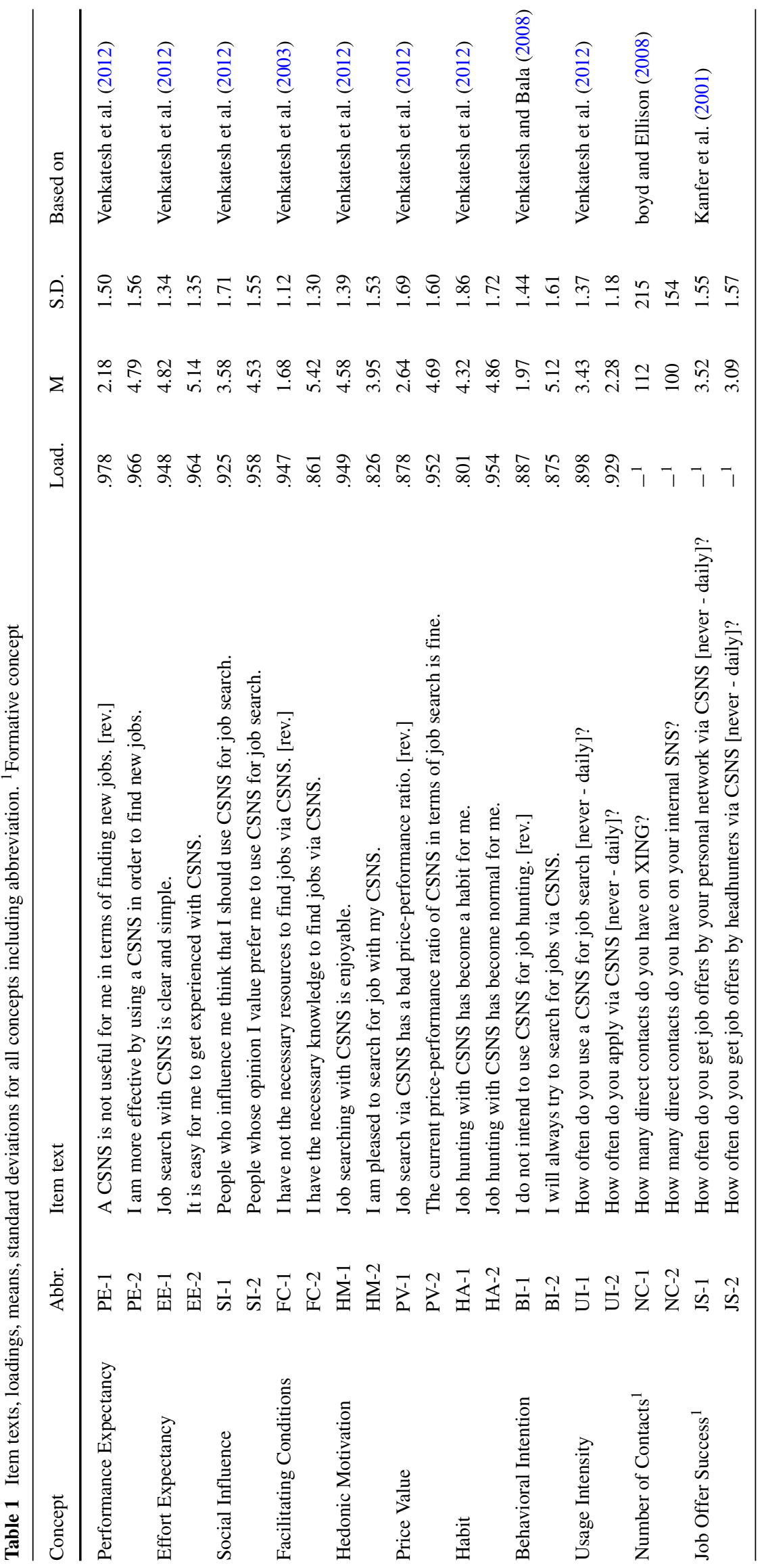


Convergent validity: In order to evaluate the convergent validity I used the Average Variance Extracted (AVE) values of each reflective construct. In the dataset all AVEs were above .5 (see Table 2) which indicates convergent validity (cf. Hair et al. 2014).

Discriminant reliability: The discriminant validity check in terms of the cross loadings criterion according to Chin (1998) was also successful. Finally, the Fornell-Larcker criterion (Fornell and Larcker 1981) is also fulfilled as $\sqrt{\mathrm{AVE}\left(\text { construct }_{i}\right)}>\operatorname{CORR}\left(\right.$ construct $_{i}$, construct $_{j}$ ) (see Table 2).

\section{Formative constructs}

Following the guidelines by Henseler et al. (2009) I report indicator validity and construct validity for the evaluation of the formative constructs.

Indicator validity: Each formative indicator was relevant due to a significance level of $\mathrm{p}<.001$ (nonparametric bootstrapping procedure according to Efron and Tibshirani (1993) with 5,000 samples) and absolute path coefficients above .2 (cf. Chin 1998). In addition, I can report that multicollinearity is not an issue since variance inflation factors (VIFs) were below 5 (cf. Hair et al. 2014, pp. 125).

Construct validity: Discriminant validity was also sufficient since the interconstruct correlations between the formative constructs and all other constructs were below .71 (cf. MacKenzie et al. 2005).

In summary I can state that the measurement model is valid (cf. Hair et al. 2014).

\section{Structural model results}

To investigate the latent structure of the constructs and their causal relations, a structural equation model was conducted using smartPLS (Ringle et al. 2005), which provides very robust model estimates, regardless of the distributional properties (Hair et al. 2014, p. 22). The model used the indicators as described in Table 1. Significance levels were assessed by the bootstrapping algorithm of smartPLS (Ringle et al. 2005) with $\mathrm{n}=5,000$ samples.

Model validity: Through the model shown in Fig. 2 excellent quality measures were achieved and Job Offer Success (JS) can be strongly explained $\left(\mathrm{R}_{J S}^{2}=.805\right)$. Moreover, the predictive relevance $Q^{2}$ (Geisser 1974; Stone 1974) of the model was evaluated. Using the blindfolding procedure of smartPLS (Ringle et al. 2005), $\mathrm{Q}^{2}$ values larger than zero for the reflective endogenous latent variables were calculated
$\left(\mathrm{Q}_{B I}^{2}=.654, \mathrm{Q}_{U I}^{2}=.272\right)$ which indicates the model's predictive relevance (Hair et al. 2014). Finally post-hoc power analyzes also revealed a very good statistical power value of 1.0 ( $\gg$ 0.80, cf. Peng and Lai (2012, p. 473)).

Model analysis: What is really interesting is the substantial negative effect of the Number of Contacts on Job Offer Success $\left(\mathrm{p}_{N C-J S}=-.521\right)$. The Number of Contacts is sufficiently explained by the Usage Intensity $\left(\mathrm{R}_{N C}^{2}=.617\right.$, pUI-NC $=.570)$ which in turn is predicted by the Behavioral Intention $\left(\mathrm{R}_{\mathrm{UI}}^{2}=.359\right.$, p $\left.\mathrm{UI-NC}=.462\right)$. The Behavioral Intention is mainly influenced by Facilitating Conditions and Habit $\left(\mathrm{p}_{\mathrm{FC}-\mathrm{BI}}=.600, \mathrm{p}_{\mathrm{HA}-\mathrm{BI}}=.362\right)$.

I found that the Number of Contacts partially mediates the effect of Usage Intensity on Job Offer Success (Sobel (1982) test, $\mathrm{p}<.001)$. A full mediator effect of the Number of Contacts does not exist since the direct effect of Behavioral Intention on Job Offer Success still remained significant, but at a lower level $(\mathrm{p}<.05)$.

When deleting the Number of Contacts concept, the model substantially lost predictive quality. This reduced model reached an explanation of 19 percent $\left(\mathrm{R}_{\mathrm{JS}}^{2}=.190\right)$ which means only a weak effect (Urbach and Ahlemann 2010 , p. 21). Also the path coefficients were only smallmedium (Chin 1998; Cohen 1988).

The Usage Intensity partially mediates the influence of Behavioral Intention on Job Offer Success (Sobel (1982) test, $\mathrm{p}<.001)$. If this mediator is also deleted, the model power in terms of JS variance is even smaller $\left(\mathrm{R}_{\mathrm{JS}}^{2}=.126\right)$.

In the present sample there is a small correlation between age and the number of contacts $(\mathrm{r}=.22, \mathrm{p}<.01)$. This result is in line with previous work showing that at the beginning of an individual's professional activity its social network changes and contacts to more and more new colleagues will be established during the ensuing professional life (e.g., Jones 1996; Pfeil et al. 2009). In our case this growing network is reflected in the career-oriented social networking

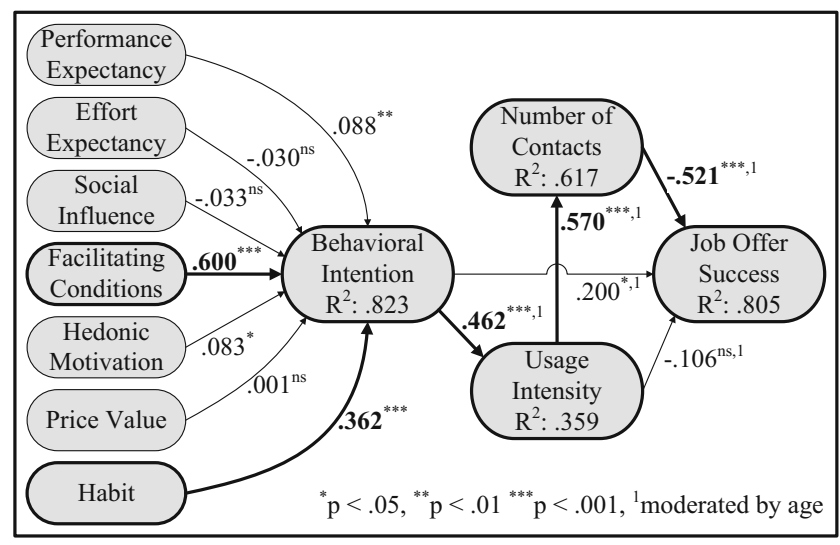

Fig. 2 Structural equation model results. Thick paths mean that the absolute path coefficients are greater than .2 
Table 2 Quality Criteria of the Measurement Model: Average Variance Extracted (AVE), Cronbach's $(\alpha)$, Composite Reliability (CR), Diagonal contains $\sqrt{\mathrm{AVE}}$ values

\begin{tabular}{lllllllllllllll}
\hline & AVE & $\alpha$ & CR & PE & EE & SI & FC & HM & PV & HA & BI & UI & NC & JS \\
\hline PE & .945 & .942 & .971 & .972 & & & & & & & & & \\
EE & .914 & .906 & .955 & .637 & .956 & & & & & & & & \\
SI & .886 & .874 & .940 & .346 & .212 & .941 & & & & & & & \\
FC & .819 & .789 & .900 & .141 & .748 & .141 & .905 & & & & & & \\
HM & .792 & .755 & .883 & .619 & .686 & .611 & .393 & .890 & & & & & \\
PV & .839 & .817 & .912 & .748 & .557 & .011 & .443 & .463 & .916 & & & & \\
HA & .776 & .737 & .873 & .716 & .574 & .353 & .422 & .530 & .676 & .881 & & & \\
BI & .776 & .712 & .874 & .767 & .733 & .254 & .817 & .525 & .599 & .694 & .881 & & \\
UI & .834 & .802 & .910 & .476 & .246 & .323 & .210 & .309 & .305 & .511 & .372 & .913 & & \\
NC & -1 & -1 & -1 & .166 & .000 & .035 & -.078 & .145 & -.029 & -.049 & .028 & .430 & -1 & \\
JS & -1 & -1 & -1 & -.118 & .314 & .125 & .148 & .116 & -.052 & .334 & .140 & -.261 & -.698 & -1 \\
\hline
\end{tabular}

${ }^{1}$ Formative concept market XING. It is important to note that there is no correlation between age and job offer success $(\mathrm{r}=.06, \mathrm{p}=.36)$. Thus, age does not explain getting job offers, a finding which is also in line with previous research (e.g., Huselid and Day 1991).

\section{Discussion}

\section{What is the role of the number of contacts in terms of getting job offers via career-oriented social networking markets $\left(\mathrm{RQ}_{1}\right)$ ?}

By integrating the number of contacts as a new concept in UTAUT2, its predictive quality substantially rises from 19.0 percent to 80.5 percent. However, as stated within the structural model results section, the counterproductive role of Number of Contacts in terms of getting job offers ( $\mathrm{p}_{\text {NC-JS }}=$ -.521 ) is surprising. Granovetter (1995) stressed the important role of contacts for getting jobs several decades ago. A lot of other scholars also confirmed the value of weak and strong ties, in particular for getting job offers (Granovetter 1973; Burt 1992; Borgatti and Halgin 2011; Garg and Telang 2012) and also that shareholders act on the basis of "The more, the better". The only doubt came from practitioners, especially from professional headhunters (e.g., Zanella and Pais 2014; Wanberg et al. 2000), stating that the relevance of the number of contacts is negligible. While the work by Wanberg et al. (2000) was related to unemployed job seekers and offline carrier-oriented social networks, this work is related to online career-oriented social networking markets and is not restricted to a specific group, i.e., unemployed job seekers. The results of this work support the gut instinct of professional headhunters and the call by Donath and boyd (2004) that simply "collecting contacts" does not make sense. This result is of importance for the evolution of online social networks (Pößneck et al. 2012).

A further post-hoc analysis of potential nonlinear relationships between the user's number of contacts and its job offer success revealed very interesting results (see Fig. 3).

As shown in Fig. 3 the relation between the Number of Contacts and Job Offer Success is nonlinear. The success rate increases rapidly from zero to 157 contacts where it reaches its maximum level (slightly lower than 'high success'), before falling back to a level substantially below 'neutral success' at about 400 contacts. Participants

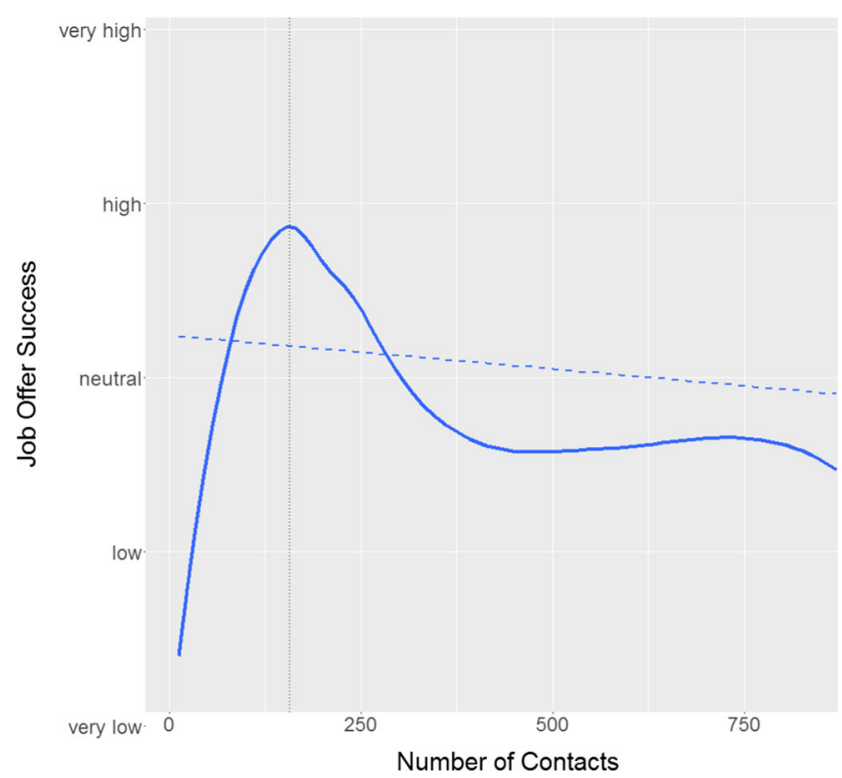

Fig. 3 At a peak of about 157 contacts, people reported the maximum amount of job offer success. [full line: smoothed relationship; dashed line: linear relationship] 
with more than 400 contacts report at an average that they have not so much success in terms of getting job offers. The reason why these figures are really interesting is that Dunbar found in zoology and sociology that a primates/humans group size of around 150 individuals is the most effective one (e.g., Dunbar 2003, 2008). This constant regarding an effective group size is constrained by neocortex size in primates including humans (Dunbar 1992). That is why the mean group size of human clans is also about 150 (Dunbar 1998) - the same number (157) which was also found in this study.

Likewise Gonçalves et al. (2011) analyzed " a dataset of Twitter conversations collected across six months involving 1.7 million individuals and test the theoretical cognitive limit on the number of stable social relationships" and found that "users can entertain a maximum of 100-200 stable relationships" (p. 1). The work by Gonçalves et al. (2011) and my work support the findings by Dunbar also for internetbased social networks. Consequently we can speculate that in (career-oriented) social networking applications the full market potential can also be reached by having about 150 social ties. It can be speculated that in long-term the market regulates the amount of a user's contacts up or down to achieve Dunbar's number through selection. In summary $\mathrm{H}_{12}$ is not supported by the data.

I also found no support for $\mathrm{H}_{10}$ since the relationship between Usage Intensity and Job Offer Success was negative in my investigation. However, I can support $\mathrm{H}_{8}, \mathrm{H}_{9}$ and $\mathrm{H}_{11}$.

\section{What drives the intention to use career-oriented social networking markets for a job search $\left(\mathrm{RQ}_{2}\right)$ ?}

In contrast to prior general technology acceptance research (e.g., Davis 1989; Venkatesh et al. 2003, 2012), I found no positive relationship between Effort Expectancy or Social Influence or Price Value and Behavioral Intention (no support of $\mathrm{H}_{2}, \mathrm{H}_{3}$ and $\mathrm{H}_{6}$ ). The previously theorized positive influences of both Performance Expectancy and Hedonic Motivations on Behavioral Intention were also evident in my investigation concerning significance but only at a negligible effect size level $\left(\mathrm{f}_{\mathrm{PE}}^{2}=.006, f_{\mathrm{HM}}^{2}=.017\right.$, cf. Cohen (1988); Chin (1998)). That is why I can also not support $\mathrm{H}_{1}$ and $\mathrm{H}_{5}$.

However I found a strong impact of Facilitating Conditions on Behavioral Intentions (support of $\mathrm{H}_{4}$ ). This result confirms the major role of sufficient resources and knowledge previously theorized in economics (Alchian 1969; Alchian and Demsetz 1972; Stigler 1961), human resources (McCall 1970; Spence 1973) and IS research (Venkatesh et al. 2012; Deng and Chi 2012; Deng and Davidson 2013; Deng and Liu 2013; Deng and Wang 2013).

My results also show that Habit substantially forms Behavioral Intention in terms of job search via careeroriented social networking markets (support of $\mathrm{H}_{7}$ ). But this is surprising and in contrast to prior knowledge from offline job searches. Prior research argued that a "job search typically is a nonroutine and complex task, for which little automatic script structures are available, it requires continuous conscious processing and self-regulation (Van Hooft et al. 2012, p. 9). Cognitive processes in an offline job search comprises a behavioral phase of goal striving, directional maintenance, volitional control, maintaining of the planned activities as well as reflection and revision (Van Hooft et al. 2012) - indicating a high level of conscious processing. However, the substantial influence of Habit on Behavioral Intention which I found in my investigation was theorized in general IT use (Kim et al. 2005; Limayem et al. 2007; LaRose and Eastin 2004) and social media usage (Hutto and Bell 2014; Nikou and Bouwman 2013). This result indicates that a job search as a nonroutine and complex task may in principle be potentially transformed into an automatic unconscious procedure by means of CSNM usage (cf. Ouellette and Wood 1998).

The investigation shed light on CSNM usage for the job search and the study results are useful for scholars and practitioners.

\section{Theoretical implications}

From a theoretical point of view it is interesting that only Facilitating Conditions and Habit are the (substantial) predictors of Behavioral Intention. In addition, the counterproductive role of having more than 157 contacts for Job Offer Success is interesting for further theoretical work in information systems. The counterproductive role was not theorized previously, but was often reported by practitioners (e.g., Zanella and Pais 2014, p. 6) and argued by Dunbar (2003).

With the advent of online social networks in the internet era it was speculated that this new class of information technology enables the establishment of new contacts and the maintaining of existing relationships - especially over long distances. Actually, scholars found that people are using online social networking to connect, in particular, with some new contacts but mostly with other known contacts (Subrahmanyam et al. 2008; Reich and Subrahmanyam 2012) and to maintain existing friendships (boyd and Ellison 2008; Ellison et al. 2011). Online social networking is often used to "...connect acquaintances who do not frequently interact and, therefore, might not strongly influence each another" (Bitter and Grabner-Kräuter 2016, p. 222).

While online social networks sometimes differ in their structure from offline networks (e.g., "celebrities and sports figures use social media networks to communicate directly with fans with whom they have no offline relationship" (Kane et al. 2014, p. 280)), they have many parallels (see Table 3). 
Table 3 Tie related differences between offline and online social networks

\begin{tabular}{|c|c|c|}
\hline Characteristic & Offline social network & Online social network \\
\hline Degree centrality & $\begin{array}{l}\text { While the number of cognitively } \\
\text { manageable ties is limited to } \\
\text { about } 150 \text { (Dunbar 2003), most } \\
\text { people report having 14-56 ties } \\
\text { at average (Granovetter 1983; } \\
\text { van Tilburg 1995; Christakis and } \\
\text { Fowler 2009) }\end{array}$ & $\begin{array}{l}\text { Huge amount of ties technologi- } \\
\text { cally possible, but average num- } \\
\text { ber is limited, e.g., Facebook: } 395 \\
\text { (Tong et al. 2008), LinkedIn: } 149 \\
\text { (Utz 2016), XING: } 121 \text { (Buet- } \\
\text { tner 2016c), Twitter: 150-250 } \\
\text { (Gonçalves et al. 2011; Hofer and } \\
\text { Aubert 2013) }\end{array}$ \\
\hline Symmetry & $\begin{array}{l}\text { Usually symmetric (reciprocal } \\
\text { behavior, cf. Buettner }(2009))\end{array}$ & $\begin{array}{l}\text { Symmetric (e.g., Facebook, } \\
\text { LinkedIn, XING, cf. Buettner } \\
\text { (2016d)) and asymmetric (e.g., } \\
\text { Twitter, cf. Buettner and Buettner } \\
(2016) \text { ) }\end{array}$ \\
\hline Affect & $\begin{array}{l}\text { Positive }(92-97 \%) \text { and negative } \\
(3-8 \%) \text { tie relationships (Kane } \\
\text { et al. 2014) can be managed using } \\
\text { high sophisticated coordination } \\
\text { mechanisms such as argumen- } \\
\text { tation and negotiation (Buettner } \\
\text { 2006a, b; Landes and Buettner } \\
\text { 2012; Buettner 2016a) }\end{array}$ & $\begin{array}{l}\text { Except through blocking (e.g., } \\
\text { Twitter) or hiding (e.g., Face- } \\
\text { book) limited support to deal with } \\
\text { negative tie relationships }\end{array}$ \\
\hline Strength & $\begin{array}{l}2-8 \text { strong ties and } 12-48 \\
\text { weak/latent ties on average } \\
\text { (Granovetter 1983; Christakis } \\
\text { and Fowler 2009) }\end{array}$ & $\begin{array}{l}\text { 9-37 strong ties and 68-131 } \\
\text { weak/latent ties on average } \\
\text { (Levin and Cross 2004; De Meo } \\
\text { et al. 2014; Utz 2016) }\end{array}$ \\
\hline Dynamic of change & $\begin{array}{l}\text { Low due to manual interaction } \\
\text { (Freeman 1977; Miritello et al. } \\
\text { 2013) }\end{array}$ & $\begin{array}{l}\text { High because of technological } \\
\text { support (Miritello et al. 2013; } \\
\text { Kane et al. 2014) }\end{array}$ \\
\hline
\end{tabular}

As shown in Table 3, tie symmetry and affect characteristics are quite similarly pronounced in offline and online networks. In contrast to these similarities, people often report having more (strong and weak) ties online than offline. However, most online ties are typically weak (Levin and Cross 2004; De Meo et al. 2014; Utz 2016).

Generally, scholars found more similarities than differences between online and offline social networks. In rare cases online social network ties are simply echoes of offline social relationships (e.g., Lampe et al. 2006), but online structures are often correlated in (multiplex) offline social networks (e.g., Ibarra 1992; Borgatti et al. 2009; Borgatti and Halgin 2011; Kane et al. 2014). Hence, there are substantial overlaps between participants' online and offline networks. A recent analysis by Dunbar et al. (2015) indicated that "online communities have very similar structural characteristics to offline face-to-face networks" (p. 39). In addition, longitudinal studies suggest that online social network interaction changes the tie strength of existing offline networks (e.g., Burke and Kraut 2014). Thus both type of social networks, online and offline, potentially converged in the long run.

However, since people often report having more contacts online than offline, from a theoretical point of view it is interesting to investigate whether Dunbar's number is increasing due to the usage of online social networks. For instance, Tong et al. (2008) revealed an inverted u-shaped relationship between the number of friends a Facebook profile has and its social (not physical) attractiveness at a peak of about 300 friends, which indicates such an increase.

\section{Practical implications}

Furthermore, the results are also fruitful for both CSNM operators and users. Operators can enhance CSNM by improving the job search functions and its explanations. The study revealed the need for sufficient knowledge and resources to form a user's intention to use a CSNM for a job search. That is why it is recommended that CSNM operators systematically assess the user's knowledge-related problems in order to make CSNM use habitual for a user. It is important to remember that Facilitating Conditions and Habit are the substantial factors for forming a user's intention to use a CSNM for a job search.

In addition, users benefit from the insight that simply "collecting contacts" (Donath and boyd 2004) does not make sense in terms of getting job offers. This insight is interesting for users because it was found that SNS users pri- 
marily construct their network on the basis of expectations regarding the value of networking (Krasnova et al. 2010). Since an optimal number of 157 contacts were found in this study and this number is in line with Dunbar's findings and similar work by other authors (e.g., Gonçalves et al. 2011), CSNM operators could implement more sophisticated recommendation mechanisms in order to regulate the number of online contacts a user has (Pößneck et al. 2012). This also includes the recommendation of online social network pruning.

\section{Conclusion}

In this paper I empirically analyzed the relationship between the number of CSNM contacts a person has (as the most important centrality measure (Shaw 1954)) and CSNM outcome in terms of getting job offers by integrating the number of contacts as an independent construct into Venkatesh's et al. UTAUT2 model (Venkatesh et al. 2012). By asking 523 participants and subsequently analyzing by means of structural equation modeling, I found that due to the integration of the number of contacts as an independent concept in UTAUT2 its predictive quality substantially rises from 19.0 percent to 80.5 percent. In addition, I found a substantial negative relationship between the number of contacts for an amount of contacts above 157 and job search success, which supports the experiences of practitioners (Zanella and Pais 2014, p. 6) and questions the value propositions of all career-oriented social networking sites. Furthermore, I revealed that resources and knowledge about job search functions in CSNM mainly drive job search intentions, which confirms speculation from new institutional economics about job search markets (e.g., McCall 1970; Spence 1973). In addition, in contrast to prior research from human resources concerning offline job search behavior (e.g., Van Hooft et al. 2012), I found evidence that habit also plays an important role in building job search intention in CSNM.

\section{Limitations}

The main limitation of the study concerns the operationalization of the centrality measure, i.e. Number of Contacts. There is no doubt that the number of contacts is the most common centrality measure (cf. Shaw 1954), but there are much more sophisticated ones (cf. Borgatti and Everett 2006; Borgatti and Halgin 2011).

Another limitation is related to the measurement of the Job Offer Success concept. Since it is neither possible to retrieve the exact number of job offers from the XING application nor from its API, I decided to operationalize this construct using two items measuring perceived job offer success. However, this measure could be (slightly) biased because psychological research has documented systematic errors in all retrospective evaluations (cf. Kahneman et al. 1997; Podsakoff et al. 2003, 2012).

Since this study was carried out in Germany and solely assessed the XING network where the members predominantly speak German, the present findings should not be thoughtlessly generalized to other CSNMs and/or other countries.

Since the focus of this study was only on receiving job offers as the outcome of CSNM, the recommendation of regulating the number of online contacts by CSNM operators including online social network pruning is only related to optimizing the receipt of job offers. Despite other studies also revealing inverted $\mathrm{u}$-shaped relationships between the number of contacts and benefits, such as the highest social (not physical) attractiveness of Facebook users having about 300 friends (Tong et al. 2008), the present findings should not be thoughtlessly generalized to all possible CSNM benefits. For example, while career development is the essential purpose for LinkedIn users (Florenthal 2015) as an important CSNM, interpersonal communication, building an online identity and information search are the primary purposes for using Facebook or MySpace.

Furthermore, I controlled the sample only by age and gender. As shown in Fig. 2 the relationships to the outcome variables were moderated by age. However, I did not control for other variables such as personality, education, duration of unemployment, financial status, etc.

\section{Future research}

Future research should investigate the relationship between the number of contacts and job offer success in more detail, for example, by adding concepts concerning the contact collecting attitudes and behavior (e.g., senselessly collecting contacts versus a conscious approach). In addition, other factors potentially influencing job offer success (e.g., local events by XING), could be evaluated.

Future work should also investigate the role of other network centrality measures (Borgatti and Everett 2006; Borgatti and Halgin 2011) concerning the impact of Job Offer Success in CSNM. For instance, using a survey data of 109 unemployed job seekers, Garg and Telang (2012) found that weak ties are especially helpful in generating job leads but it is the strong ties that play an important role in generating job interviews and job offers. That is why the use of other centrality measures than the number of contacts could be fruitful for further IS-theorizing. In addition, the initial evidence that CSNM can transform job search activities as a nonroutine and complex task into automatic unconscious processes could also be fruitful for subsequent investigations. 
In addition, replication studies for other CSNMs such as LinkedIn and countries other than Germany should evaluate the present findings.

Furthermore, social network centrality measures are not only interesting for receiving job offers but also for other career-related outcomes (e.g., job performance, life satisfaction, health) or more general social commerce benefits (Zhou et al. 2013; Baethge et al. 2016). That is why future research should also shift the focus to these outcomes.

Acknowledgments I would like to thank the two anonymous reviewers and the responsible editor who each provided very helpful comments on the refinement of the manuscript. An earlier version of this article was presented at the 49th Hawaii International Conference on System Sciences (HICSS) in 2016 and appeared in the HICSS-49 proceedings (cf. Buettner 2016b). This research was partly funded by the German Federal Ministry of Education and Research (03FH055PX2).

Open Access This article is distributed under the terms of the Creative Commons Attribution 4.0 International License (http:// creativecommons.org/licenses/by/4.0/), which permits unrestricted use, distribution, and reproduction in any medium, provided you give appropriate credit to the original author(s) and the source, provide a link to the Creative Commons license, and indicate if changes were made.

\section{References}

Akter, S., \& Wamba, S.F. (2016). Big data analytics in E-commerce: a systematic review and agenda for future research. Electronic Markets, 26(2), 173-194.

Alchian, A.A. (1969). Information costs, pricing and resource unemployment. Western Economic Journal, 7(2), 109-128.

Alchian, A.A., \& Demsetz, H. (1972). Production, information costs, and economic organization. American Economic Review, 62(5), 777-795.

Alt, R., \& Klein, S. (2011). Twenty years of electronic markets research - looking backwards towards the future. Electronic Markets, 21, 41-51.

Alt, R., \& Zimmermann, H.-D. (2014). Editorial 24/3: Electronic Markets and general research. Electronic Markets, 24(3), 161-164.

Baethge, C., Klier, J., \& Klier, M. (2016). Social commerce - state-ofthe-art and future research directions. Electronic Markets, 26(3), 269-290.

Baldwin, T.T., Bedell, M.D., \& Johnson, J.L. (1997). The social fabric of a Team-Based M.B.A. Program: Network effects on student satisfaction and performance. The Academy of Management Journal, 40(6), 1369-1397.

Bitter, S., \& Grabner-Kräuter, S. (2016). Consequences of customer engagement behavior: when negative Facebook posts have positive effects. Electronic Markets, 26(3), 219-231.

Borgatti, S.P., \& Everett, M.G. (2006). A Graph-theoretic perspective on centrality. Social Networks, 28(4), 466-484.

Borgatti, S.P., \& Halgin, D.S. (2011). On network theory. Organization Science, 22(5), 1168-1181.

Borgatti, S.P., Mehra, A., Brass, D.J., \& Labianca, G. (2009). Network analysis in the social sciences. Science, 323(5916), 892-895. boyd, D.M., \& Ellison, N.B. (2008). Social network sites: definition, History, and Scholarship. Journal of Computer-Mediated Communication, 13(1), 210-230.

Brecht, F., \& Eckhardt, A. (2012). Employer branding via social network sites - A silver bullet to attract it professionals? In ECIS '12 Proc. paper 89.

Briscoe, B., Odlyzko, A., \& Tilly, B. (2006). Metcalfe's law is wrong communications networks increase in value as they add membersbut by how much? IEEE Spectrum, 43(7), 34-39.

Buettner, R. (2006a). A classification structure for automated negotiations. In 2006 IEEE/WIC/ACM International conference on web intelligence and intelligent agent technology (WI-IAT 2006 Workshops Proceedings), Hong Kong, China IEEE, Los Alamitos, CA, USA (pp. 523-530).

Buettner, R. (2006b). The State of the Art in Automated Negotiation Models of the Behavior and Information Perspective. International Transactions on Systems Science and Applications (ITSSA), 1(4), 351-356. special Issue Section of the Fourth German Conference on Multi-Agent System Technologies (MATES06), Selected Papers, 19.-20. September 2006, Erfurt, Germany.

Buettner, R. (2007a). Electronic Negotiations of the Transactional Costs Perspective. In Proceedings of IADIS International Conference WWW/Internet, Vol. 2, Vila Real, Portugal, October 5-8, 2007 International Association for Development of the Information Society (IADIS) Press (pp. 99-105).

Buettner, R. (2007b). Imperfect Information in Electronic Negotiations: An Empirical Study. In Proceedings of IADIS International Conference WWW/Internet, Vol. 2, Vila Real, Portugal, October 5-8, 2007 International Association for Development of the Information Society (IADIS) Press (pp. 116-121).

Buettner, R. (2009). Cooperation in Hunting and Food-sharing: A Two-Player Bio-inspired Trust Model. In BIONETICS '09: Proceedings Of the fourth international conference on bio-inspired models of network, information, and computing systems (BIONETICS '09), avignon, France, December 9-11, 2009 Springer-Verlag LNICST, (Vol. 39 pp. 1-10).

Buettner, R. (2014). A Framework for Recommender Systems in Online Social Network Recruiting. In HICSS 2014 Proceedings: 47th Hawaii International Conference on System Sciences (HICSS-47), January 6-9, 2014, Big Island, Hawaii (pp. 1415-1424).

Buettner, R. (2015a). A Systematic Literature Review of Crowdsourcing Research from a Human Resource Management Perspective. In HICSS-48 Proc (pp. 4609-4618).

Buettner, R. (2015b). Analyzing the Problem of Employee Internal Social Network Site Avoidance: Are Users Resistant due to their Privacy Concerns? In HICSS-48 Proc (pp. 1819-1828).

Buettner, R. (2015c). Towards a New Personal Information Technology Acceptance Model: Conceptualization and Empirical Evidence from a Bring Your Own Device Dataset. In AMCIS 15903 Proc.

Buettner, R. (2016a). A user's cognitive workload perspective in negotiation support systems: An eye-tracking experiment. In: PACIS 2016 Proceedings: 20th Pacific Asia Conference on Information Systems (PACIS), June 27 - July 1, Chiayi, Taiwan (115).

Buettner, R. (2016b). Getting a Job via Career-oriented Social Networking Sites: The Weakness of Ties. In HICSS-49 Proc (pp. 2156-2165).

Buettner, R. (2016c). Innovative Personality-based Digital Services. In PACIS 2016 Proceedings: 20th Pacic Asia Conference on Information Systems (PACIS), June 27 - July 1, Chiayi, Taiwan (278).

Buettner, R. (2016d). Personality as a predictor of business social media usage: An empirical investigation of XING usage patterns. In PACIS 2016 Proceedings: 20th Pacific Asia Conference on Information Systems (PACIS), June 27 - July 1, Chiayi, Taiwan (163).

Buettner, R. (2016e). Predicting user behavior in electronic markets based on personality-mining in large online social networks: a personality-based product recommender framework. Electronic Markets (pp. 1-19). In press. 
Buettner, R., \& Buettner, K. (2016). A Systematic Literature Review of Twitter Research from a Socio-Political Revolution Perspective. In HICSS-49 Proc (pp. 2206-2215).

Buettner, R., \& Landes, J. (2012). Web service-based applications for electronic labor markets: a multi-dimensional price vcg auction with individual utilities. In ICIW 2012: Proc. of the 7th International Conference on Internet and Web Applications and Services, May 27 - June 1, 2012, Stuttgart, Germany IARIA, Stuttgart, Germany (pp. 168-177).

Buettner, R., Daxenberger, B., \& Woesle, C. (2013). User acceptance in different electronic negotiation systems - a comparative approach. In ICEBE 2013: Proceedings of the 10th IEEE international conference on e-business engineering, September 11 - 13, Coventry, UK IEEE CS Press (pp. 1-8).

Burke, M., \& Kraut, R. (2014). Growing Closer on Facebook: Changes in Tie Strength Through Social Network Site Use. In CHI'14 Proc. Toronto, ON, Canada (pp. 4187-4196).

Burt, R.S. (1992). Structural holes: The social structure of competition. HUP.

Caers, R., \& Castelyns, V. (2011). Linkedin and Facebook in Belgium: The influences and biases of social network sites in recruitment and selection procedures. Social Science Computer Review, 29(4), 437-448.

Cao, J., Gao, H., Li, L.E., \& Friedman, B. (2013). Enterprise social network analysis and modeling: A tale of two graphs. In IEEE INFOCOM '13 Proc. (pp. 2382-2390).

Carmines, E.G., \& Zeller, R.A. (1979). Reliability and Validity Assessment. Beverly Hills: Sage.

Chin, W.W. (1998). The Partial Least Squares Approach for Structural Equation Modeling Modern Methods for Business Research. In Marcoulides, G.A. (Ed.) Lawrence Erlbaum Associates, Mahwah (pp. 295-336).

Christakis, N.A., \& Fowler, J.H. (2009). Connected the surprising power of our social networks and how they shape our lives. New York: LB \& Company.

Cohen, J. (1988). Statistical power analysis for the behavioral sciences, 2nd edn. NJ: Lawrence Erlbaum Hillsdale.

Davis, F.D. (1989). Perceived usefulness, perceived ease of use, and user acceptance of information technology. MIS Quarterly, 13(3), 319-340.

De Meo, P., Ferrara, E., Fiumara, G., \& Provetti, A. (2014). On Facebook, most ties are weak. Communications of the ACM, 57(11), 7884

Deng, X.N., \& Chi, E.H. (2012). Understanding postadoptive behaviors in information systems use: a longitudinal analysis of system use problems in the business intelligence context. Journal of Management Information Systems, 29(3), 291-326.

Deng, X.N., \& Davidson, E.J. (2013). Knowledge boundaries and spanning practices in configuring packaged systems. Journal of Information Technology Case and Application Research, 15(1), 37-66.

Deng, X.N., \& Liu, Y. (2013). Understanding knowledge transfer dynamics in information system support: an exploratory study of procurement system support. In HICSS-46 Proc. (pp. 3674-3683).

Deng, X.N., \& Wang, T. (2013). Understanding Customer-Oriented Organizational Citizenship Behavior in Information System Support: An Exploratory Study. In HICSS-46 Proc. (pp. 4115-4124).

van Dijck, J. (2013). You have one identity: performing the self on Facebook and LinkedIn. Media, Culture \& Society, 35(2), 199-215.

Dodds, W.B., Monroe, K.B., \& Grewal, D. (1991). Effects of price, brand, and store information on buyers. Journal of Marketing Research, 28(3), 307-319.

Doherty, R. (2010). Getting social with recruitment. Strategic HR Review, 9(6), 11-15.

Donath, J., \& boyd, d. (2004). Public Displays of Connection. BT Technology Journal, 22(4), 71-82.
Dunbar, R.I.M. (1992). Neocortex size as a constraint on group size in primates. Journal of Human Evolution, 22(6), 469-493.

Dunbar, R.I.M. (1998). The social brain hypothesis. Evolutionary Anthropology, 6(5), 178-190.

Dunbar, R.I.M. (2003). Evolution of the social brain. Science, 302(5648), 1160-1161.

Dunbar, R.I.M. (2008). Cognitive constraints on the structure and dynamics of social networks. Group dynamics: Theory. Research, and Practice, 12(1), 7-16.

Dunbar, R.I.M., Arnaboldi, V., Conti, M., \& Passarella, A. (2015). The structure of online social networks mirrors those in the offline world. Social Networks, 43, 39-47.

Efron, B., \& Tibshirani, R.J. (1993). An Introduction to the Bootstrap. Chapman \& Hall.

Ellison, N.B., Steinfield, C., \& Lampe, C. (2011). Connection strategies: Social capital implications of Facebook-enabled communication practices. New Media \& Society, 13(6), 873-892.

Enders, A., Hungenberg, H., Denker, H.-P., \& Mauch, S. (2008). The long tail of social networking. Revenue models of social networking sites. European Management Journal, 26(3), 199-211.

Florenthal, B. (2015). Applying uses and gratifications theory to students LinkedIn usage. Young Consumers, 16(1), 17-35.

Fornell, C., \& Larcker, D.F. (1981). Evaluating structural equation models with unobservable variables and measurement error. Journal of Marketing Research, 18(1), 39-50.

Freeman, L.C. (1977). A set of measures of centrality based on betweenness. Sociometry, 40(1), 35-41.

Freeman, L.C. (1978). Centrality in social networks: Conceptual clarification. Social Networks, 1(3), 215-239.

Gandal, N., King, C.I., \& Van Alstyne, M. (2009). The social network within a management recruiting firm: Network structure and output. Review of Network Economics, 8(4), (article 2).

Garg, R., \& Telang, R. (2012). Role of Online Social Networks in Job Search by Unemployed Individuals. In ICIS '12 Proc.

Geisser, S. (1974). A predictive approach to the random effect model. Biometrika, 61(1), 101-107.

Gonçalves, B., Perra, N., \& Vespignani, A. (2011). Modeling users' activity on twitter networks: Validation of dunbar's number. $P L O S$ ONE, 6(8), e22,656.

Granovetter, M.S. (1973). The strength of weak ties. American Journal of Sociology, 78(6), 1360-1380.

Granovetter, M.S. (1983). The strength of weak ties: a network theory revisited. Sociological Theory, 1(1), 201-233.

Granovetter, M.S. (1995). Getting a Job: A Study of Contacts and Careers, 2nd edn. Chicago: University of Chicago Press.

Hair, J.F., Ringle, C.M., \& Sarstedt, M. (2011). PLS-SEM: Indeed A silverbullet. Journal of Marketing Theory \& Practice, 19(2), 139-152.

Hair, J.F., Hult, G.T.M., Ringle, C.M., \& Sarstedt, M. (2014). A primer on partial least squares structural equation modeling (PLS-SEM). Thousand Oaks: Sage.

Hassenzahl, M. (2001). The effect of perceived hedonic quality on product appealingness. International Journal of Human Computer Interaction, 13(4), 481-499.

van der Heijden, H. (2004). User acceptance of hedonic information systems. MIS Quarterly, 28(4), 695-704.

Henseler, J., Ringle, C.M., \& Sinkovics, R.R. (2009). The use of partial least squares path modeling in international marketing. In Sinkovics, R. R., \& Ghauri, P. N. (Eds.) New Challenges to International Marketing (Advances in International Marketing, Emerald (Vvol. 20, pp. 277-319).

Hofer, M., \& Aubert, V. (2013). Perceived bridging and bonding social capital on Twitter: Differentiating between followers and followees. Computers in Human Behavior, 29(6), 2134-2142.

Huselid, M.A., \& Day, N.E. (1991). Organizational commitment, job involvement, and turnover: a substantive and methodological analysis. Journal of Applied Psychology, 76(3), 380-391. 
Hutto, C., \& Bell, C. (2014). Social Media Gerontology: Understanding Social Media Usage among a Unique and Expanding Community of Users. In HICSS-47 Proc. (pp. 1755-1764).

Ibarra, H. (1992). Homophily and differential returns: Sex differences in network structure and access in an advertising firm. Administrative Science Quarterly, 37(3), 422-447.

Jones, C. (1996). The boundaryless career. A New Employment Principle for a New Organizational Era Oxford University Press chap Careers in Project Networks: The Case of the Film Industry pp. 58-75.

Kahneman, D., Wakker, P.P., \& Sarin, R. (1997). Back to bentham? explorations of experienced utility. Quarterly Journal of Economics, 112(2), 375-406.

Kane, G.C., Alavi, M., Labianca, G., \& Borgatti, S. (2014). What's different about social media networks?: a framework and research agenda. MIS Quarterly, 38(1), 275-304.

Kanfer, R., Wanberg, C.R., \& Kantrowitz, T.M. (2001). Job search and employment: a Personality-Motivational analysis and MetaAnalytic review. JAP, 86(5), 837-855.

Keim, T. (2007). Extending the Applicability of Recommender Systems: A Multilayer Framework for Matching Human Resources. In HICSS 2007 Proceedings (p. 169).

Kim, S.S., Malhotra, N.K., \& Narasimhan, S. (2005). Two competing perspectives on automatic use: a theoretical and empirical comparison. Information Systems Research, 16(4), 418-432.

Krasnova, H., Koroleva, K., \& Veltri, N.F. (2010). Investigation of the network construction behavior on social networking sites. In ICIS '10 Proc. paper 182.

Kraut, R., Patterson, M., Lundmark, V., Kiesler, S., Mukophadhyay, T., \& Scherlis, W. (1998). Internet paradox: a social technology that reduces social involvement and psychological well-being? American Psychologist, 53(9), 1017-1031.

Kraut, R., Kiesler, S., Boneva, B., Cummings, J., Helgeson, V., \& Crawford, A. (2002). Internet paradox revisited. Journal of Social Issues, 58(1), 49-74.

Kügler, M., Smolnik, S., \& Raeth, P. (2013). Determining the Factors Influencing Enterprise Social Software Usage: Development of a Measurement Instrument for Empirical Assessment. In HICSS '13 Proc. (pp. 3635-3644).

Kuhn, P., \& Mansour, H. (2014). Is internet job search still ineffective? The Economic Journal, 124(581), 1213-1233.

Lampe, C., Ellison, N., \& Steinfield, C. (2006). A Face(Book) in the crowd: Social Searching vs. Social Browsing. In CSCW'06 Proc. Banff, Alberta, Canada (pp. 167-170).

Landes, J., \& Buettner, R. (2011). Job Allocation in a Temporary Employment Agency via Multidimensional Price VCG Auctions Using a Multi-agent System. In MICAI 2011: 10th Mexican International Conference on Artificial Intelligence, November 26 December 4, 2011, Puebla, Mexico IEEE Computer Society Press (pp. 182-187).

Landes, J., \& Buettner, R. (2012). Argumentation-Based Negotiation? Negotiation-Based argumentation! In Huemer, C., Lops, P. (Eds.) Proc. of EC-web 2012: 13th International Conference on Electronic Commerce and Web Technologies, September 3 - 7, 2012, Vienna, Austria Springer, Berlin / Heidelberg LNBIP (Vol. 123, pp. 149-162).

LaRose, R., \& Eastin, M.S. (2004). A social cognitive theory of internet uses and gratifications: Toward a new model of media attendance. Journal of Broadcasting \& Electronic Media, 48(3), 358-377.

Levin, D.Z., \& Cross, R. (2004). The strength of weak ties you can trust: The mediating role of trust in effective knowledge transfer. Management Science, 50(11), 1477-1490.

Limayem, M., Hirt, S.G., \& Cheung, C.M.K. (2007). How habit limits the predictive power of intention: The case of information systems continuance. MIS Quarterly, 31(4), 705-737.
Luo, X., Zhang, J., \& Duan, W. (2012). Social media and firm equity value. Information Systems Research, 24(1), 146-163.

Macdonald, S. (1986). Headhunting in high technology. Technovation, 4(3), 233-245.

MacKenzie, S.B., Podsakoff, P.M., \& Jarvis, C.B. (2005). The problem of measurement model misspecification in behavioral and organizational research and some recommended solutions. Journal of Applied Psychology, 90(4), 710-730.

Madia, S.A. (2011). Best practices for using social media as a recruitment strategy. Strategic HR Review, 10(6), 19-24.

McCall, J.J. (1970). Economics of information and job search. Quarterly Journal of Economics, 84(1), 113-126.

Mehra, A., Dixon, A.L., Brass, D.J., \& Robertson, B. (2006). The social network ties of group leaders: Implications for group performance and leader reputation. Organization Science, 17(1), 64 79.

Miritello, G., Lara, R., Cebrian, M., \& Moro, E. (2013). Limited communication capacity unveils strategies for human interaction. Scientific Reports, 3(1950), 1-7.

Nikou, S., \& Bouwman, H. (2013). The Diffusion of Mobile Social Network Service in China: The Role of Habit and Social Influence. In HICSS-46 Proc. (pp. 1073-1081).

Nunnally, J.C., \& Bernstein, I.H. (1994). Psychometric Theory, 3rd edn. New York: McGraw-Hill.

Oechslein, O., Fleischmann, M., \& Hess, T. (2014). An Application of UTAUT2 on Social Recommender Systems: Incorporating Social Information for Performance Expectancy. In HICSS-47 Proc. (pp. 3297-3306).

Ollington, N., Gibb, J., \& Harcourt, M. (2013). Online social networks: an emergent recruiter tool for attracting and screening. Personnel Review, 42(3), 248-265.

Ouellette, J.A., \& Wood, W. (1998). Habit and intention in everyday life: The multiple processes by which past behavior predicts future behavior. Psychological Bulletin, 124(1), 54-74.

Parks, M.R., \& Floyd, K. (1996). Making friends in cyberspace. Journal of Communication, 46(1), 80-97.

Peng, D.X., \& Lai, F. (2012). Using partial least squares in operations management research: a practical guideline and summary of past research. Journal of Operations Management, 30(6), 467-480.

Petter, S., Straub, D., \& Rai, A. (2007). Specifying formative constructs in information systems research. MIS Quarterly, 31(4), 623-656.

Pfeil, U., Arjan, R., \& Zaphiris, P. (2009). Age differences in online social networking - A study of user profiles and the social capital divide among teenagers and older users in MySpace. Computers in Human Behavior, 25(3), 643-654.

Plummer, M., Hiltz, S.R., \& Plotnick, L. (2011). Predicting Intentions to Apply for Jobs Using Social Networking Sites: An Exploratory Study. In HICSS '11 Proc. (pp. 1-10).

Plummer, M.M., \& Hiltz, S.R. (2009). Recruitment in Social Networking Sites: A Theoretical Model of Jobseekers' Intentions. In AMCIS '09 Proc. paper 176.

Podsakoff, P.M., MacKenzie, S.B., Lee, J.-Y., \& Podsakoff, N.P. (2003). Common method biases in behavioral research: a critical review of the literature and recommended remedies. Journal of Applied Psychology, 88(5), 879-903.

Podsakoff, P.M., MacKenzie, S.B., \& Podsakoff, N.P. (2012). Sources of method bias in social science research and recommendations on how to control it. Annual Review of Psychology, 63, 539-69.

Pößneck, L., Hofmann, H., \& Buettner, R. (2012). Physical theories of the evolution of online social networks: a discussion impulse. In Proc. of ICIW 2012: 7th International Conference on Internet and Web Applications and Services, May 27 - June 1, 2012, Stuttgart, Germany (pp. 137-142).

Przemyslaw, K., Szozda, N., Filipowski, T., \& Blysz, W. (2013). New business client acquisition using social networking sites. Electronic Markets, 23(2), 93-103. 
Raeth, P., \& Smolnik, S. (2010). Antecedents and Consequences of Corporate Weblog Usage in the Intranet: A Process Perspective. In HICSS '10 Proc. (pp. 1-10).

Rangan, S. (2000). The problem of search and deliberation in economic action: When social networks really matter. Academy of Management Review, 25(4), 813-828.

Reich, S.M., \& Subrahmanyam, K. (2012). Friending, IMing, and Hanging Out Face-to-Face: Overlap in Adolescents' Online and Offline Social Networks. Developmental Psychology, 48(2), 356-368.

Revelle, W. (1979). Hierarchical clustering and the internal structure of tests. Multivariate Behavioral Research, 14(1), 57-74.

Ringle, C.M., Wende, S., \& Will, A. (2005). Smartpls 2.0 (beta). http:// www.smartpls.de.

Ringle, C.M., Sarstedt, M., \& Straub, D.W. (2012). Editor's Comments: A Critical Look at the Use of PLS-SEM in MIS Quarterly. MIS Quarterly, 36(1), iii-xiv.

Robinson, J.P., \& Martin, S. (2010). IT Use and declining social capital? more cold water from the general social survey (GSS) and the american Time-Use survey (ATUS). Social Science Computer Review, 28(1), 45-63.

Saks, A.M. (2006). Multiple predictors and criteria of job search success. Journal of Vocational Behavior, 68(3), 400-415.

Seibert, S.E., Kraimer, M.L., \& Liden, R.C. (2001). A social capital theory of career success. The Academy of Management Journal, 44(2), 219-237.

Shaw, M.E. (1954). Group structure and the behavior of individuals in small groups. The Journal of Psychology: Interdisciplinary and Applied, 38(1), 139-149.

Smith, W.P., \& Kidder, D.L. (2010). You've been tagged! (Then again, maybe not): Employers and Facebook. Business Horizons, 53(5), 491-499.

Sobel, M.E. (1982). Asymptotic confidence intervals for indirect effects in structural equation models. Sociological Methodology, 13, 290-312.

Sparrowe, R.T., Liden, R.C., Wayne, S.J., \& Kraimer, M.L. (2001). Social networks and the performance of individuals and groups. The Academy of Management Journal, 44(2), 316-325.

Spence, A.M. (1973). Job market signaling. Quarterly Journal of Economics, 87(3), 355-374.

Steinhueser, M., Richter, A., \& Smolnik, S. (2015). How to bridge the boundary? Determinants of inter-organizational social software usage. Electronic Markets, 25(4), 267-281.

Stigler, G.J. (1961). The economics of information. Journal of Political Economy, 69(3), 213-225.

Stone, M. (1974). Cross-Validatory Choice and assessment of statistical predictions. Journal of the Royal Statistical Society Series B (Methodological), 36(2), 111-147.

Subrahmanyam, K., Reich, S.M., Waechter, N., \& Espinoza, G. (2008). Online and of !ine social networks: Use of social networking sites by emerging adults. Journal of Applied Developmental Psychology, 29(6), 420-433.

Sugianto, L.-F., \& Tojib, D.R. (2006). Modeling user satisfaction with an employee portal. International Journal of Business and Information, 1(2), 239-255.

Takac, C., Hinz, O., \& Spann, M. (2011). The social embeddedness of decision making: opportunities and challenges. Electronic Markets, 21(3), 185-195.

Tan, T., Zhang, Y., \& Kankanhalli, A. (2014). How online social networks affect my job choice intention: an empirical approach. In PACIS '14 Proc. paper 324.

Teigland, R., Wasko, M., \& Landqvuist, F. (2006). Examining knowledge exchange and organizational outcomes within intraorganizational electronic networks of practice with restricted access. In ECIS '06 Proc. paper 143.
Thatcher, J., Dinger, M., \& George, J.F. (2012). Information technology worker recruitment: an empirical examination of Entry-Level IT job seekers labor market. Communications of the Association for Information Systems, 31, 1-34.

van Tilburg, T.G. (1995). Living arrangements and social networks of older adults VU University Press, Amsterdam chap Delineation of the social network and differences in network size, pp. 83-96.

Tojib, D.R., Sugianto, L.-F., \& Sendjaya, S. (2008). User satisfaction with business-to-employee portals: conceptualization and scale development. European Journal of Information Systems, 17(6), 649-667.

Tong, S.T., Van Der Heide, B., Langwell, L., \& Walther, J.B. (2008). Too much of a good thing? the relationship between number of friends and interpersonal impressions on facebook. Journal of Computer-Mediated Communication, 13(3), 531-549.

Urbach, N., \& Ahlemann, F. (2010). Structural equation modeling in information systems research using partial least squares. Journal of Information Technology Theory and Application, 11(2), 5-40.

Urbach, N., Smolnik, S., \& Riempp, G. (2010). An empirical investigation of employee portal success. Journal of Strategic Information Systems, 19(3), 184-206.

Urbach, N., Smolnik, S., \& Riempp, G. (2011). Determining the Improvement Potentials of Employee Portals Using a Performance-based Analysis. Business Process Management Journal, 17(5), 829-845.

Utz, S. (2016). Is LinkedIn making you more successful? The informational benefits derived from public social media. New Media \& Society, 18(11), 2685-2702.

Van Hooft, E.A.J., Wanberg, C.R., \& van Hoye, G. (2012). Moving beyond job search quantity: Towards a conceptualization and self-regulatory framework of job search quality. Organizational Psychology Review, 3(1), 3-40.

Venkatesh, V., \& Bala, H. (2008). Technology acceptance model 3 and a research agenda on interventions. Decision Sciences, 39(2), 273-315.

Venkatesh, V., Morris, M.G., Davis, G.B., \& Davis, F.D. (2003). User acceptance of information technology: Toward a unified view. MIS Quarterly, 27(3), 425-478.

Venkatesh, V., Thong, J.Y.L., \& Xu, X. (2012). Consumer acceptance and use of information technology: Extending the unified theory of acceptance and use of technology. MIS Quarterly, 36(1), 157178.

Wanberg, C.R., Kanfer, R., \& Banas, J.T. (2000). Predictors and outcomes of networking intensity among unemployed job seekers. Journal of Applied Psychology, 85(4), 491-503.

Zanella, S., \& Pais, I. (2014). The Adecco Global Study 2014: Job Search, Digital Reputation and HR Practices in the social media age. Adecco Group. http://www.adecco.com/en-US/Industry-Insig hts/Documents/social-recruiting/adecco-global-social-recruiting-s urvey-global-report.pdf.

Zhang, J., \& Ackerman, M.S. (2005). Searching for Expertise in Social Networks: A Simulation of Potential Strategies. In Proceedings of the 2005 international ACM SIGGROUP conference on Supporting group work ACM, New York, NY, USA GROUP '05 (pp. 71-80).

Zhao, S. (2006). Do internet users have more social ties? A call for differentiated analyses of internet use. Journal of ComputerMediated Communication, 11(3), 844-862.

Zhou, L., Zhang, P., \& Zimmermann, H.-D. (2013). Social commerce research: an integrated view. Electronic Commerce Research and Applications, 12(2), 61-68.

Zhou, X., Xu, Y., Li, Y., Josang, A., \& Cox, C. (2012). The state-ofthe-art in personalized recommender systems for social networking. Artificial Intelligence Review, 37(2), 119-132. 